\title{
Follow the Money. Introduction to the Special Issue 'Financial Aspects of Organized Crime'
}

\author{
Edward R. Kleemans ${ }^{1}$
}

Published online: 31 May 2015

(C) Springer Science+Business Media Dordrecht 2015

Organized crime emerged suddenly on the political and law enforcement agenda in many European countries in the 1980s and 1990s. The increasing focus on financial aspects of organized crime followed suit, but at a much slower pace. Anti-money laundering efforts were actively promoted by some governments and organizations such as the Financial Action Task Force (FATF), but were also opposed by other parties, as some measures impose a high burden on certain economic sectors (see for a review, e.g., Levi and Reuter 2006; Levi 2013; Kilchling 2014; Halliday et al. 2014). These sustained anti-money laundering efforts gained new momentum through the shocking terrorist attacks in New York (2001), Madrid (2004), and London (2005), and several recent incidents in European countries and abroad. Consequently, the discussion has been widened from organized crime (with a strong emphasis on drug trafficking) to terrorism and terrorist funding, although these phenomena and the financial aspects of these phenomena may be quite different in several respects.

The discussion on money laundering has a strong policy focus and is dominated by untested assumptions about offenders and offender behavior, and the impact of criminal networks and criminal activities on society. Can organized crime activities and terrorism be lumped together or should they be treated separately? What influence does money have on these phenomena and is this different for different aspects such as investing money in criminal activities, moving and laundering proceeds of crime, and investing money in legal economy? What is the impact of money laundering on the integrity of the financial system and on society as a whole? Is it really a big threat and in what respect? Can money laundering be curbed through specific crime prevention strategies and investigation strategies ('follow the money')? And how should these new strategies be integrated in the law enforcement system?

Empirical research into financial aspects of organized crime is very important to test the assumptions that are part of public debate, but are often taken for granted, not explicated, and put to the empirical test. Despite the importance of this task, academic researchers - with a few notable exceptions - have not paid a lot of attention to these salient questions. Therefore,

Edward R. Kleemans

e.r.kleemans@vu.nl

1 VU School of Criminology, Faculty of Law, VU University Amsterdam, De Boelelaan 1105, 1081HV Amsterdam, The Netherlands 
this special issue of the European Journal on Criminal Policy and Research presents research that gives us more insight into the financial aspects of organized crime. It includes two papers on investments in two different countries with divergent organized crime situations (Italy and the Netherlands), a paper on persons facilitating the movement and laundering of crime money, and a paper on a neglected aspect of the discussion: how criminal activities are financed and how this differs from the financing of licit businesses.

The first paper by Savona focuses on the revenues and investments of Italian Mafias. First, revenues are estimated to be much lower than the figure currently circulating in the press. According to these new estimates, the highest revenues in Italy originate from drug trafficking, followed by extortion, sexual exploitation, and counterfeiting. Second, the article analyzes information on seized assets of Mafia groups over a long period of time (1983-2011), distinguishing between real estate (land and buildings), companies and corporate bonds, registered properties (principally motor vehicles), and other registered properties (cash or valuables). Savona concludes that the largest share of investments was allocated to the purchase of real estate (52.3\%; primarily residential buildings), followed by registered property $(20.6 \%)$, other registered property $(18.4 \%)$, and companies and corporate bonds $(8.7 \%)$. The criminal investments in real estate appear to be serving mostly the operational needs of the organization and the primary needs of Mafia members and their families, whereas the purchase of real estate for investments seems to be of minor importance. Moreover, analysis of the drivers of the investments in real estate and the areas in which investments are made lead to the conclusion that the control of the territory might be a more important factor to explain Mafia investment decisions than economic factors (such as profitability). There is no positive and significant correlation between the level of profitability of an industry and the decision by Mafias to invest in it. Conversely, Mafias tend to invest primarily in sectors characterized by low labor productivity, sectors characterized by small and medium companies, areas marked by an intense Mafia presence, poor infrastructural endowment, and low levels of the development of the economy and of the banking/financial system.

It is interesting to compare these conclusions on Italy with the conclusions of the second paper on investments of organized crime offenders in the Netherlands. As we know, the situation in many European countries is quite different from the situation in Italy, where Mafia presence and Mafia control of certain regions and sectors of industry have a long history (see, e.g., Paoli 2003; Varese 2011). Conversely, in many other European countries, control of regions and business sectors by organized crime groups is a far less common problem. For example, in the Netherlands the primary business of organized crime groups is not racketeering, but 'transit crime' (Kleemans 2007): international criminal activities such as drug trafficking, smuggling illegal immigrants, human trafficking for sexual exploitation, arms trafficking, trafficking in stolen vehicles, and other transnational illegal activities, such as money laundering and evasion of taxes (cigarette smuggling, European Community fraud, for example). Transit crime does not require corruption, Mafia control, or racketeering. In fact, it may benefit from reliable government and an excellent infrastructure for the transportation of legal (and illegal) goods, a transit country such as the Netherlands being a prime example. What do criminal investments look like in a transit country such as the Netherlands?

Kruisbergen, Kleemans, and Kouwenberg use empirical data from the Dutch Organized Crime Monitor to give empirical insight into the choices organized crime offenders make when they invest their money in legal economy. They use a dataset of 1196 individual investments and investigate what kind of assets offenders purchase and where these assets are located. The background of this article consists of three different theoretical perspectives and assumptions 
that are present in the literature on money laundering and organized crime: the standard economic approach ('profit'), the criminal infiltration approach ('power'), and social opportunity structure ('proximity') (Kleemans and De Poot 2008). The results of the study show that offenders predominantly invest in their country of origin or in their country of residence and that their investments consist of tangible, familiar assets such as residences and other real estate and (small) companies from well-known sectors. Investments such as bonds, options, and stocks in companies in which offenders are not personally (or indirectly) involved were only found in a small number of cases. In other words: offenders usually stay close to home with their investments. So, instead of profitability or power, proximity seems to be a better description of their investment choices. Comparing the main conclusions of investments in Italy and the Netherlands, it is interesting to note that the conclusions are quite similar, despite the widely diverging organized crime situations in these countries. Proponents of the standard economic approach, suggesting that offenders are highly flexible and search for the most profitable regions and the most profitable economic sectors, seem to have put the discussion on money laundering and seized assets on the wrong track. On the contrary, social opportunity structure ('proximity') and territorial control are important factors to take into account as well.

The third article by Soudijn focuses on hawala or underground banking networks and the relationship with money laundering. For many migrants, hawala is a traditional, cheap, and flexible way to move money to other countries, but the same system can be used by criminals to move or launder their illicit proceeds. In the past, some authors argued that there are several reasons why hawala bankers would not get involved in moving criminal proceeds (e.g., Passas 1999), but empirical evidence demonstrated convincingly that criminals do make use of hawaladars (e.g., Kleemans et al. 2002; Passas 2005). How are hawala bankers able to tell the difference between migrant remittances and crime money and how can the police distinguish between ignorant hawala bankers and people who are knowingly involved in the movement of criminal proceeds? Soudijn analyzes seven main police investigations (and 28 subsidiary investigations) in the Netherlands and describes seven 'red flags' that may signal the movement of criminal proceeds: large amounts of money, frequency, routing, token use, changing 500-euro notes, contacts with persons of a different ethnicity, and illogical business operations. Soudijn concludes that this empirical knowledge can be used as subjective indicators; points of departure that the service provider can use in the case of transactions that arouse suspicion. Furthermore, he argues that these 'red flags' can also be used by the police to identify hawala bankers that reasonably can be found guilty of money laundering. Finally, Soudijn uses this empirical evidence to discuss the possibilities and impossibilities of formal financial supervision of the hawala sector.

In the last article, Levi focuses on a neglected aspect of the discussion: how criminal activities are financed and how this differs from the financing of licit businesses. The first part of the article shows how illicit financing might and does operate. A key issue is the social capital of offenders and their access to illicit finance. Levi ironically concludes that access to illicit finance may be easier, if controls make it harder to launder money, as more criminal reinvestment capital may be made available due to the difficulties and risks of 'real' laundering. The second part of the article reviews international evidence on money laundering, most notably in the US, Canada, the Netherlands, the United Kingdom, Bulgaria, Germany, Italy, Spain, and the Nordic countries. The main conclusion is that the most commonly prosecuted money laundering cases are not complicated. However, this does not mean that there are no complicated cases, since the proportion of crime proceeds and crime financing that have been 
subjected to serious investigation is modest. Finally, Levi discusses the policy relevance of these findings.

"Follow the money" is an advice that has often been given to criminal justice authorities. Criminal justice authorities have more or less responded to this call and investigation practices are changing slowly. Now it is time for academic researchers to follow suit.

\section{References}

Halliday, T., Levi, M., \& Reuter, P. (2014). Assessments of Anti-Money Laundering and Combating the Financing of Terrorism. Chicago: American Bar Foundation.

Kilchling, M. (2014). Finance-Oriented Strategies of Organized Crime Control'. In L. Paoli (Ed.), The Oxford Handbook of Organized Crime (pp. 655-673). New York: Oxford University Press.

Kleemans, E.R. (2007). Organized Crime, Transit Crime, and Racketeering. Crime and Justice. A Review of Research 35, 163-215. Chicago: The University of Chicago Press.

Kleemans, E. R., \& De Poot, C. J. (2008). Criminal Careers in Organized Crime and Social Opportunity Structure. European Journal of Criminology, 5(1), 69-98.

Kleemans, E. R., Brienen, M. E. I., \& Van de Bunt, H. G. (2002). Georganiseerde Criminaliteit in Nederland. Tweede Rapportage op basis van de WODC-Monitor. The Hague: WODC.

Levi, M. (2013). Drug Law Enforcement and Financial Investigation Strategies. Modernising Drug Law Enforcement - Report 5. London: International Drug Policy Consortium.

Levi, M., \& Reuter, P. (2006). Money Laundering. Crime and Justice. A Review of Research 34, $289-375$. Chicago: The University of Chicago Press.

Paoli, L. (2003). Mafia Brotherhoods: Organized Crime, Italian Style. New York: Oxford University Press.

Passas, N. (1999). Informal Value Transfer Systems and Criminal Organizations: A Study into So-Called Underground Banking Networks. The Hague: WODC.

Passas, N. (2005). Informal Value Transfer Systems and Criminal Activities. The Hague: WODC.

Varese, F. (2011). Mafias on the Move. Princeton: Princeton University Press. 